\begin{tabular}{ccc}
\hline & $\begin{array}{c}\text { International Journal of Health Services } \\
\text { Research and Policy } \\
\text { www.dergipark.org.tr/ijhsrp }\end{array}$ \\
INTERNATIONAL & ENGINEERING \\
SCIENCE AND & e-ISSN: 2602-3482 \\
EDUCATION GROUP & IJHSRP \\
\hline
\end{tabular}

Research Article

\title{
THE EFFECTS OF A STRUCTURED TRAINING PROGRAM ON THE IDENTIFICATION AND EVALUATION OF FORENSIC CASES BY NURSES
}

\author{
Funda TOSUN GÜLEROĞLU ${ }^{1}$ (]) Gökçen AYDIN AKBU $\breve{G} A^{2}$ (D) \\ Dilek EFE ARSLAN ${ }^{3 *}$ (1) Esin CERITT ${ }^{4}$ (1) Aybike BAHÇELI ${ }^{2}$ (1) \\ ${ }^{1}$ Yozgat Bozok University, Faculty of Health Sciences, Yozgat, Turkey \\ ${ }^{2}$ Yozgat Bozok University, Faculty of Health Sciences, Yozgat, Turkey \\ ${ }^{3}$ Erciyes University, Vocational School of Health Services, Kayseri Turkey \\ ${ }^{4}$ Yozgat Bozok University, Faculty of Health Sciences, Yozgat, Turkey \\ *Corresponding author: dilekefe_@hotmail.com
}

\begin{abstract}
This study was conducted to determine the effect of a structured education program on the ability of nurses to identify and evaluate forensic cases. The study is an intervention study with a pretest, post-test, and follow-up test design. The population of the study is composed of 130 nurses working in a University Research and Application Hospital in Central Anatolia in Turkey. The sample size was not calculated as the aim was to reach the whole population. The study was completed with 42 nurses who agreed to participate in the study. The data of the study were collected by using the Nurse Information form and Forensic Cases Identification and Evaluation Knowledge form. The pre-test was done one week earlier than the training, the post-test was done just after the training, and follow-up was done one month later after the training. The average age of the nurses was found to be $30.11 \pm 4.87,69 \%$ of the participants were married, and 59.5\% hold a bachelor's degree. When nurses' Forensic Case Identification and Evaluation Information Form mean scores were compared, the mean score was $4.57 \pm 1.98$ in the pre-test, $11.73 \pm 4.09$ in post-test, and 9.88 13.40 in follow-up done one month later. It was determined that there was a significant increase in nurses' average of the post-test and follow-up scores according to pre-test $(p<0.05)$. It was found that the number of the nurses' correct answers regarding the collection of evidence increased significantly after training and in the follow-up. It has been determined that education has a positive effect on the level of knowledge about the identification and assessment of forensic cases. It is recommended that nurses be given in-service training on the evaluation of forensic cases and evidence identification, collection, and recording. Also, forensic nursing certificate programs can be made more common.
\end{abstract}

Keywords: Nurse, Forensic case, Structured education

Received: November 23, 2020

Accepted: March 26, 2021 


\section{Introduction}

All injuries which result from intentional, careless, and inattentive behavior of another, from incompetence in the profession, or from not complying with the instructions and orders and the injuries which cause suspicion of poisoning and whose purpose is suicide are defined as forensic cases. Also, all accidents involving trauma are considered possible forensic cases until the reason behind the accident is uncovered [1]. In case of a forensic case, nurses are one of the first group of healthcare personnel both the victim and the offender encounter. Thus, forensic nurses who have received specialized education or special training in forensic medicine have critical importance within the forensic team [2]. Forensic nurses have roles and responsibilities in criminal cases such as becoming aware of the incident, filing the story about the forensic case, physical evaluation, forensic examination, collecting and storing biological and physical evidence, protecting the safety chain, writing up the forensic report, and providing support to the victims and their relatives. However, the job definition of forensic nurses has not yet been made in our country. Thus, the roles and responsibilities of forensic nurses have to be fulfilled by clinic nurses [2,3].

Clinical nurses play an active role in forensic cases. It is not a new situation for nurses to encounter forensic cases; however, they cannot adopt the right approach in forensic cases as they do not have sufficient knowledge and experience about forensic medicine and forensic nursing [4]. It is possible that nurses without sufficient knowledge and experience do not realize the evidence and do not know the procedures and techniques of identifying, collecting, and storing evidence. As a result, evidence can be damaged, lost, or destroyed, which is an undesirable situation [5,6]. However, a mistake or an incomplete practice during the medical examination of a forensic case may affect the analysis of the case, and thus on the result.

Lack of knowledge and experience in forensic medicine not only affects the forensic review process but may also cause health care personnel to receive legal punishment. The purpose of the Penal Code is to protect individual's rights and freedoms, public order, and security, the rule of law, peace in the community, public health, and the environment and preventing crime [7]. As stated in Article 280 of the Turkish Penal Code, a health care Professional (physicians, dentists, pharmacists, midwives, nurses, etc.) who do not report a crime to the authorities or who has been delayed in reporting it despite having an indication on duty that a crime was committed, is sentenced to maximum one-year imprisonment. No law in Turkey clearly expresses the concept of forensic nursing, but as one of the most common health personnel with forensic incidents, nurses should be able to cope with this situation competently. Because the criminal law states that, all health personnel has criminal liability in case of negligence or postponement of duty. Also, a health care professional who does not have sufficient knowledge and skills in forensic medicine and evaluation may violate the law without knowing about the article in question. However, it should not be forgotten that as Article 4 of the Turkish Penal Code states, "Ignorance of the law does not excuse" [7].

Scientific research studies have revealed that the vast majority of nurses encounter forensic cases, that there are deficiencies in collecting and storing forensic evidence, delivering it to the relevant authorities, and evaluating forensic cases, and that education and approaches related to forensic cases are not adequate [8,9]. A study conducted with emergency nurses showed that 95 percent of the nurses have not received education about forensic nursing [10]. The importance of the correct nursing approach to forensic cases has recently been acknowledged, and forensic nursing courses have been included in 
the undergraduate and graduate curricula of the nursing departments of many universities [11-13] as elective courses. This situation shows that attempts are made to increase the awareness of nurses in forensic cases.

Developments in forensic nursing in Turkey have begun to take place in recent years. The number of scientific meetings and certified courses related to forensic nursing $\mathrm{h}$ a s increased. Moreover, as mentioned earlier, forensic nursing has gained importance in nursing education. As a result, it is believed that nurses who have received special education in forensic medicine and forensic evaluation during their undergraduate education or after graduation through in-service training or certificate programs contribute greatly to the team making the forensic evaluation and to the solution of a forensic case [2]. Furthermore, nurses' ability to make forensic assessments and the theoretical knowledge they have on this issue will both accelerate the development of forensic nursing and affect the overall quality of forensic evaluations positively.

\section{Material and Methods}

\subsection{Aim of the study}

This study was conducted to determine the effect of a structured education program on the ability of nurses to identify and evaluate forensic cases.

\subsection{Research Question}

- Does a structured education program affect the ability of nurses to identify and evaluate forensic cases?

\subsection{Setting and samples}

The study is an intervention study with a pre-test, post-test, and follow-up test design. The population of the study is composed of 130 nurses working in a University Research and Application Hospital in Central Anatolia in Turkey. The sample size was not calculated as the aim was to reach the whole population. Nurses who agreed to participate in the study and whose working hours do not prevent them from attending the training were included in the study. Nurses who did not attend all of the training were excluded from the study.

The study was concluded with 42 nurses who gave their consent to participate in the study. At the end of the research, a power analysis was conducted with the data of the research itself. $95 \%$ confidence interval and $\mathrm{p}=0.05$ significance level were used for power analysis. As a result of the power analysis, the power of the study was found to be 0.87 . The group was divided into two according to the worklist of the nurses. Because the nurses were divided into two groups to ensure education dynamics and to increase the effectiveness of education.

\subsection{Ethical Considerations}

To conduct the study, institutional permission was received from the University, Research and Application Hospital Dean's Office. Ethical approval was obtained from Bozok University, Research and Application Hospital Ethical Committee (Decision number: 2018-KAEK-189_2018.01.25_18; Date: 25.01 .2018). Written and verbal consent was obtained from the nurses participating in the study. 


\subsection{Data Collection Tools}

Nurse Information Form: The form consists of six questions developed through literature review $[14,15]$. The form includes questions about the participants' age, marital status, level of education, duration of work, and previous forensic evaluation training

Forensic Cases Identification and Evaluation Knowledge form: The data were collected through a form that includes 32 questions developed by the researchers reviewing the literature $[4,14-$ 17]. The form aimed at determining the knowledge levels of nurses regarding the identification of forensic cases, evidence protection chain, and collecting evidence. The form includes three sections. 16 questions are about forensic case definition and types of forensic cases. 6 questions are about evidence protection chain (The package/ envelope containing the evidence should be sealed and sealed with tape. It is important to write on the envelope when the evidence is collected, whoever receives the evidence should write his name and position in the notebook, etc.). 10 questions are about collecting evidence such as hair, blood, urine, semen, saliva, gunpowder, etc., evaluating and photographing wounds, and removing clothes in the section on collecting evidence in forensic cases.

Expert opinion was obtained to evaluate the questionnaire. In the question form, each statement answered correctly was given 1 point, and each incorrect answer was given 0 points. The scores they got from the correct answers were collected and their level of knowledge was calculated.

\subsection{Data Collection}

To evaluate the clarity of the designed data collection tools, ease of answering the questions, and the response time, five nurses were applied the data collection forms two weeks before the education program. Following the pre-application, the questions forms were not changed.

First Stage- Pre-test: The first stage was conducted about one week before the education. The researcher explained the aim of the study to the voluntary participants, and oral and written consent was obtained from them. The forms were filled in under the supervision of the researcher in about 20 minutes.

Second Stage-Post test: The individuals who gave their consent to take part in the education group were given the structured education program. The education was given in two sessions by the same researcher. The education program was implemented once a week in a 40-minute session. In the first session, the types of forensic cases and approaches to forensic cases were discussed. In the second session, the collection of evidence, the roles, and responsibilities of the nurse were explained and participants were asked to evaluate the training program. The second stage of the research was performed immediately after training.

Follow-up Stage: The third measurement was performed one month after training to measure the effect of time.

\subsection{Data Analysis}

The data were analyzed on the computer. While analyzing the data, descriptive statistical methods (Percentage calculations, Mean, Median, and Standard Deviation), Paired Sample T-Test, and Repeated Measures Anova were used. The results were found significant at a $95 \%$ confidence interval $(p<0.05)$. 


\section{Results}

The average age of the nurses was found to be $30.11 \pm 4.87$; 69 percent of the participants were married, and 59.5\% hold a bachelor's degree. Average years of work experience was found to be $7.54 \pm 4.36$, and $40.5 \%$ of the participants have been working in the intensive care unit. $81 \%$ of the nurses stated that they have not received any education on forensic evaluation (Table 1).

Table 1. Distribution of Nurses based on their Descriptive Characteristics and Forensic Evaluation Education Status

\begin{tabular}{lcc}
\hline Characteristic & $\bar{X}$ & \pm SD \\
& & \pm 4.87 \\
Age & 30.11 & \pm 4.36 \\
Nursing experience (year) & $\mathbf{n}$ & $\mathbf{\%}$ \\
\hline & & 69.0 \\
\hline Marital status & 29 & 31.0 \\
Married & 13 & 26.2 \\
Single & 11 & 14.3 \\
\hline Education level & 6 & 59.5 \\
High school & & \\
Associate degree & 25 & \\
Bachelors & & 23.8 \\
\hline & & 16.7 \\
\hline Working services & 10 & 40.5 \\
Internal medicine & 7 & 19.0 \\
Surgical services & 17 & 19.0 \\
Intensive care & 8 & 81.0 \\
\hline Others & & 100.0 \\
\hline Previous forensic evaluation training & 8 & \\
Yes & 34 & \\
\hline Total & & \\
\hline${ }^{*}$ Health Vocational High School & 42 & \\
& & \\
\hline
\end{tabular}

The distribution of nurses' responses regarding the chain of evidence protection is included in Table 2. It was determined that 52.4.3\% (Posttest: 64.3\%, Follow-up:54.8\%) of the nurses know that all the evidence should be placed in a single envelope before the training, and 33.3\% (Posttest: 42.9\%, Follow-up:42.9\%) know that the identity information of the person collecting the evidence should remain open. In addition, it was found that $45.2 .8 \%$ (Posttest: 69. \%, Follow-up:59.5\%) of the nurses know that they should write their name and position in the evidence notebook. It was determined that the correct answers given by the nurses to the questions about the chain of evidence protection before the training increased after the training. When the follow-up was examined, it was found that the number of correct answers in the last test remained the same or decreased. 
Table 2. Distribution of Nurses' Responses Regarding the Chain of Evidence Protection (n:42)

\begin{tabular}{|c|c|c|c|c|c|c|}
\hline \multirow[t]{2}{*}{ Questions on the chain of evidence protection } & \multicolumn{2}{|c|}{ Pretest } & \multicolumn{2}{|c|}{ Posttest } & \multicolumn{2}{|c|}{ Follow-up } \\
\hline & $\mathbf{n}$ & $\%$ & $\mathbf{n}$ & $\%$ & $\mathbf{n}$ & $\%$ \\
\hline \multicolumn{7}{|l|}{ All evidence should be placed in a single envelope.* } \\
\hline True & 22 & 52.4 & 27 & 64.3 & 23 & 54.8 \\
\hline False & 20 & 47.6 & 15 & 35.7 & 19 & 45.2 \\
\hline \multicolumn{7}{|c|}{$\begin{array}{l}\text { The package/envelope containing the evidence should be sealed and } \\
\text { sealed with tape. }\end{array}$} \\
\hline True & 38 & 90.5 & 39 & 92.9 & 39 & 92.9 \\
\hline False & 4 & 9.5 & 3 & 7.1 & 3 & 7.1 \\
\hline \multicolumn{7}{|c|}{$\begin{array}{l}\text { The package/envelope should include the name of the individual, the } \\
\text { individual's protocol number, date of birth, what the sample is, where } \\
\text { and when it was received. }\end{array}$} \\
\hline True & 35 & 83.3 & 41 & 97.6 & 39 & 92.9 \\
\hline False & 7 & 16.7 & 1 & 2.4 & 3 & 7.1 \\
\hline \multicolumn{7}{|c|}{$\begin{array}{l}\text { The identity of the person collecting the evidence must remain } \\
\text { confidential.* }\end{array}$} \\
\hline True & 14 & 33.3 & 18 & 42.9 & 18 & 42.9 \\
\hline False & 28 & 66.7 & 24 & 57.1 & 24 & 57.1 \\
\hline \multicolumn{7}{|c|}{ It is important to write on the envelope when the evidence is collected. } \\
\hline True & 36 & 85.7 & 41 & 97.6 & 40 & 95.2 \\
\hline False & 6 & 14.3 & 1 & 2.4 & 2 & 4.8 \\
\hline \multicolumn{7}{|c|}{$\begin{array}{l}\text { Whoever receives the evidence should write his name and position in the } \\
\text { notebook. }\end{array}$} \\
\hline True & 19 & 45.2 & 29 & 69.0 & 25 & 59.5 \\
\hline False & 23 & 54.8 & 13 & 31.0 & 17 & 40.5 \\
\hline
\end{tabular}

The distribution of nurses' answers regarding the collecting of evidence is included in Table 3. It was determined that $16.7 \%$ of the nurses knew how the hair sample was collected before the training; this rate increased to $81 \%$ in the posttest and was $76.2 \%$ in the follow-up. It was determined that $7.12 \%$ of the nurses knew how the blood sample was collected before the training, this rate increased to $40.5 \%$ in the posttest and was $38.1 \%$ in the follow-up. It was found that the number of the nurses' correct answers regarding the collection of evidence increased significantly after training and in the follow-up.

When the averages of the scores nurses received from the judicial case identification and evaluation information form are compared, it was revealed that the pretest score average was $4.57 \pm 1.98$, while the posttest score average was $11.73 \pm 4.09$ and the follow-up test score averages obtained one month after education was $9.88 \pm 3.40$. A statistically significant difference was observed between the iterative measurement values $(p<0.001)$. Pretest score averages were found to be lower compared to posttest and follow-up score averages. It was further revealed that the posttest score average was higher than the scoring average of the follow-up test (Table 4). 
Table 3. Distribution of Nurses' Answers Regarding the Collection of Evidence (n:42)

\begin{tabular}{|c|c|c|c|c|c|c|}
\hline \multirow[b]{2}{*}{ Types of Evidence } & \multicolumn{2}{|c|}{ Pretest } & \multicolumn{2}{|c|}{ Posttest } & \multicolumn{2}{|c|}{ Follow-up } \\
\hline & & $\%$ & 1 & $\%$ & & $\%$ \\
\hline \multicolumn{7}{|l|}{ Hair } \\
\hline True & 7 & 16.7 & 34 & 81.0 & 32 & 76.2 \\
\hline False & 35 & 83.3 & 8 & 19.0 & 10 & 23.8 \\
\hline \multicolumn{7}{|l|}{ Blood } \\
\hline True & 3 & 7.1 & 17 & 40.5 & 16 & 38.1 \\
\hline False & 39 & 93.9 & 25 & 59.5 & 26 & 61.9 \\
\hline \multicolumn{7}{|l|}{ Urine } \\
\hline True & 1 & 2.4 & 9 & 21.4 & 11 & 26.2 \\
\hline False & 41 & 97.6 & 33 & 78.6 & 31 & 73.8 \\
\hline \multicolumn{7}{|l|}{ Semen and Saliva } \\
\hline True & 2 & 4.8 & 18 & 42.9 & 14 & 33.3 \\
\hline False & 40 & 95.2 & 24 & 57.1 & 28 & 66.7 \\
\hline \multicolumn{7}{|l|}{ Non-Genital Injuries } \\
\hline True & 1 & 2.4 & 13 & 31.0 & 14 & 33.3 \\
\hline False & 41 & 97.6 & 29 & 69.0 & 28 & 66.7 \\
\hline \multicolumn{7}{|l|}{ Genital Injuries } \\
\hline True & 3 & 7.1 & 18 & 42.9 & 14 & 33.3 \\
\hline False & 39 & 92.9 & 24 & 57.1 & 28 & 66.7 \\
\hline \multicolumn{7}{|l|}{ Emotional Status } \\
\hline True & 2 & 4.8 & 12 & 28.6 & 9 & 21.4 \\
\hline False & 40 & 95.2 & 30 & 71.4 & 33 & 78.6 \\
\hline \multicolumn{7}{|l|}{ Clothes } \\
\hline True & 1 & 2.4 & 27 & 64.3 & 24 & 57.1 \\
\hline False & 41 & 97.6 & 15 & 35.7 & 18 & 42.9 \\
\hline \multicolumn{7}{|l|}{ Nail Scrap } \\
\hline True & 2 & 4.8 & 13 & 31.0 & 12 & 28.6 \\
\hline False & 40 & 95.2 & 29 & 69.0 & 30 & 71.4 \\
\hline \multicolumn{7}{|l|}{ Gunpowder } \\
\hline True & 0 & 0 & 23 & 54.8 & 24 & 57.1 \\
\hline False & 42 & 100.0 & 19 & 45.2 & 18 & 42.9 \\
\hline
\end{tabular}

Table 4. Distribution of the Forensic Cases Identification and Evaluation Information Form Scores of Nurses

\begin{tabular}{llcccc}
\hline & Pretest X \pm SD & $\begin{array}{c}\text { Posttest } \\
\mathbf{X} \pm \text { SD }\end{array}$ & $\begin{array}{c}\text { Follow-up } \\
\mathbf{X} \pm \text { SD }\end{array}$ & Test $^{*}$ & Test $^{* *}$ \\
\hline $\begin{array}{l}\text { Forensic Cases Identification and } \\
\text { Evaluation Knowledge Level }\end{array}$ & $4.57 \pm 1.98^{1}$ & $11.73 \pm 4.09^{2}$ & $9.88 \pm 3.40^{3}$ & $\mathrm{p}<0.001$ & $\begin{array}{l}1<2,3 \\
2>3\end{array}$ \\
\hline
\end{tabular}

* Repeated Measures Anova **Paired Sample T-Test

\section{Discussion and Conclusions}

In Turkey, there are no laws or regulations concerning forensic nursing [17], whereas the duties and responsibilities of nurses who may encounter forensic cases were determined by laws and regulations. Furthermore, in our country, the nursing undergraduate curriculum does not adequately address content such as approaches to forensic cases, types of cases, evidence collection, and the roles 
and responsibilities of forensic nurses [18]. Consistent with the literature, this study also revealed that 81.0 percent of the nurses have not received an education on approaches to forensic cases. In their study conducted with the nurses working in emergency clinics, İlce et al. (2010) found that 65.9 percent of the participants have not participated in any conferences, seminars, or in-service training about forensic cases, and 52.3 percent of the nurses did not read publications on forensic issues [8]. Another study conducted by Gökdoğan and Erkol (2005) with nurses and nursing instructors revealed that 83.8 percent of the participants had no idea about forensic nursing and the duties of forensic nurses [9]. In a study, Topçu and Kazan (2018) have asked students about their opinions on forensic nursing, $94.7 \%$ of the students stated that there should be a field of forensic nursing in Turkey, and $42.1 \%$ of them stated that elective courses on forensic nursing should be offered in college [19]. The results of the study clearly show that nurses do not have sufficient knowledge about forensic nursing in our country.

In our study, it is seen that the level of knowledge of the nurses who were given education on types of cases, approaches to forensic cases, evidence collection, and storage increased. Moreover, it was observed through the follow-up test that the effectiveness of the education program continued even one month after the education. In a study conducted by Şentürk and Büyükaslan with students, $84 \%$ of the participants had no knowledge about forensic nursing, and 16\% were partially informed; when those who were partially informed asked about where they got the information, they answered that they obtained the information from seminars, magazines, and the internet. Also, only $12 \%$ of the students in that study reported that they had encountered a forensic case [20]. Not knowing the type of evidence, and the ways of identifying, collecting, and storing evidence may lead to the loss of evidence during treatment and care and may make forensic evaluation even more difficult [21]. Our findings indicate that subjects of forensic nursing (collecting and storing the evidence, chain of evidence protection, etc.) should be included in the curriculum of all nursing education programs and graduate programs should impart the necessary knowledge and skills to the nurses [17]. In a study assessing the knowledge level of the healthcare personnel on forensic cases, Çalışkan and Özden reported that 73\% of the health personnel did not receive training, and $17.5 \%$ of the trained ones did not find the training sufficient [22]. In the literature, we did not find any study examining the effect of a training program on forensic nursing. However, the findings of our study and other descriptive studies show that nurses have a serious need for training in forensic nursing and this need can be met with the training.

In the nursing profession, nurses may encounter forensic cases. As stated in Article 280 of the Turkish Penal Code, a health care professional, who does not report a crime to the authorities or who has been delayed in reporting it despite having an indication on duty that a crime was committed, is sentenced to a maximum of one-year imprisonment [7]. This law emphasizes the importance of nurses' approaches to forensic cases. It is believed that the education given in this study has contributed to the evaluation of forensic cases, for which nurses are responsible according to the law, and has improved the knowledge, understanding, and approaches of the nurses by drawing their attention to forensic cases [4]. The study revealed that the structured education program has had a positive effect on the knowledge levels of nurses regarding the identification and evaluation of forensic cases. As a result, it is an inevitable fact that nurses need training about the evaluation of forensic cases in our country and our study results also support that. In this respect, it is recommended to comprehensive training studies with different samples, enriched with interactive training techniques. 


\section{Recommendations}

It is recommended that nurses be given in-service training on the evaluation of forensic cases and evidence identification, collection, storage, and recording and that forensic nursing certificate programs be made more common.

Ethical Considerations: To conduct the study, institutional permission was received from the University, Research and Application Hospital Dean's Office. Ethical approval was obtained from Bozok University, Research and Application Hospital Ethical Committee (Decision number: 2018KAEK-189_2018.01.25_18; Date: 25.01.2018). Written and verbal consent was obtained from the nurses participating in the study.

Acknowledgments: The authors are grateful to the nurses who participated in this study.

Declaration of Conflicting Interest: The authors declared no potential conflicts of interest concerning the research, authorship, and/or publication of this article.

Funding: The author(s) received no financial support for the research and/or authorship of this study.

\section{References}

[1] Kavalcı, C., "Acil Serviste Adli Vaka Yönetimi. Derman Tıbbi Yayınc1lı", Journal of Clinical and Analytical Medicine, 1, 1054-1059, 2015.

[2] Fırat, S., Ünal, S., Geleş, Ç.Y., "Hemşirelikte Yeni Bir Alan: Adli Hemşirelik”, Adli Tıp Bülteni-The Bulletin of Legal Medicine. 21(1), 39-42, 2016.

[3] Koç, S., Biçer, Ü., “Adli tıbbın tarihsel gelişimi, Türkiye'deki yapılanması ve sorunları”, Klinik Gelişim, (Adli Tıp Özel Sayıs1), 22, 1-5, 2009.

[4] Çilingir, D., Hintistan, S., "Adli hemşireliğin kapsamı ve yasal boyutu”, Hemşirelikte Eğitim ve Araştırma Dergisi, 9(1), 10-15, 2012.

[5] Stevens, S. "Cracking the case: Your role in forensic nursing", Nursing, 34(11), 54-56, 2004.

[6] Özden, D., Yıldırım, N., “Adli Vakaya Hemşirelerin Yaklaşımı”, Hacettepe Üniversitesi Hemşirelik Fakültesi Dergisi, 16(3), 73-81, 2009.

[7] Turkish Penal Code (Türk Ceza Kanunu). Law Number: 5237, Acceptance Date: 26.09.2004, Published Official Gazette Date: 12.10.2004, Number of Official Gazette Published: 25611 Retrieved from: http://www.resmigazete.gov.tr/eskiler/2004/10/20041012.htm

[8] İlçe, A., Yıldız, D., Baysal, G., Özdoğan, F., Taş, F., “Acil servislerde çalışan sağlık bakım personelinin adli olgularda delillerin korunması ve saklanmasına yönelik bilgi ve uygulamalarının incelenmesi”, Ulus Travma Acil Cerrahi Derg,, 16(6), 546-51, 2010.

[9] Gökdoğan, M.R., Erkol, Z., "Forensic nursing in Bolu, Turkey: A survey”, Journal of Clinical Forensic Medicine, 12(1), 14-7, 2005. 
[10] Karataş, A.Z., Erkan, I. A., "Adli Vaka yönetiminde Acil Servis Çalı̧̧anlarının Bilgi Düzeylerinin Değerlendirilmesi” Adli Bilimler Dergisi, 15(2), 7-12, 2016.

[11] Başkent University Nursing Program Course Catalog. Retrieved from: http://angora.baskent.edu.tr/bilgipaketi/?dil=TR\&menu=akademik\&inner=katalog\&birim=617 Date of Access: 15.03.2019

[12] Dokuz Eylül University Information Package Course Catalog. Retrieved from: http://debis.deu.edu.tr/ders-katalog/2015-2016/tr/tr_1229_1229_215.html Date of Access: 15.03.2019

[13] Selçuk University, Forensic Nursing Course Content. Retrieved from: https://www.selcuk.edu.tr/saglik bilimleri fakultesi/hemsirelik/bolum dersleri/2002708/tr Date of Access: 15.03.2019

[14] Kent-Wilkinson, A., "Forensic nursing educational development: An integrated review of the literatüre", J Psychiatr Mental Health Nurs, 18(3), 236-46, 2011

[15] Lynch, V.A., Forencis Nursing Science. Forensic Nursing: A Handbook for Practice, Ed: Hammer, RM., Moynihan B, Pagliaro EM. 2nd ed. Burlington, 4-12, 2013.

[16] Çevik, S.A., Başer, M., "Adli hemşirelik ve çalışma alanları”, Sağglı Bilimleri Dergisi, 21(2),143-152, 2012.

[17] Eşiyok, B., Hanc1, İ., Özdemir, Ç., Yelken, N., Zeyfeoğlu, Y. “Adli hemşirelik”, Türk Tabipleri Birliği Sürekli Tıp Ĕ̈itimi Dergisi (STED), 13(5), 169-171, 2004.

[18] Yelken, N., Tunal1, G., Gültekin, G., “Adli hemşireliğin Türkiye'deki durumu”, Türk Tabipleri Birliği Sürekli Tıp Eğitimi Dergisi (STED), 13(5), 171-172, 2004.

[19] Topçu, E.T., Kazan, E.E., "The opinions of senior nursing students about forensic nursing", Egyptian Journal of Forensic Sciences, 8(1), 1-7, 2018

[20] Şentürk, S., Büyükaslan, B., "Hemşirelik son sınıf öğrencilerinin adli hemşirelik konusundaki bilgi ve görüşlerinin belirlenmesi” Bozok Tip Dergisi, 3(3), 19-26, 2013.

[21] Gökdoğan, .R. "Cinsel saldırı konusunda çalışan adli hemşireye (SANE) duyulan gereksinim", Adli Tıp Bülteni-The Bulletin of Legal Medicine. 13(2), 69-77, 2008.

[22] Calışkan, N., Özden, D., "The knowledge levels of health personnel in Turkey regarding forensic evidence", J Forensic Sci, 57(5), 1217-1221, 2012. 